\title{
Dedicated to Richard Wall
}

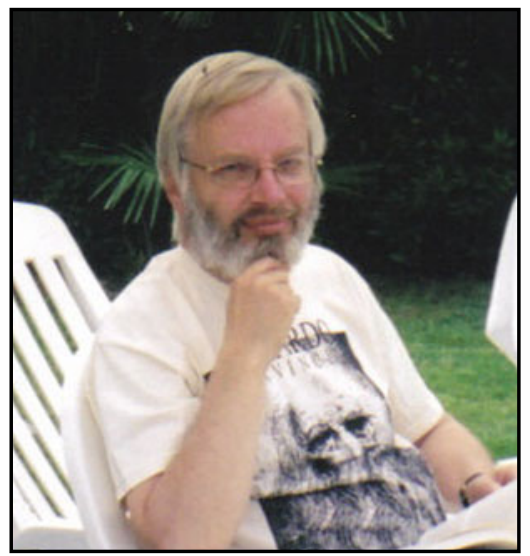

The twenty-fifth volume of Continuity and Change-including this issue and the two that follow in 2010 - is dedicated to Richard Wall, whose long-standing term as Editor of the journal reaches its conclusion in 2010.

Since the founding of Continuity and Change in 1986, the guiding hand of Richard Wall has been firmly on the tiller. His tireless commitment to nurturing scholarship in the field of historical sociology, and publishing it to the highest of editorial standards, can be felt through every page of the journal's 72 -issue history. It has been a privilege to watch Richard in action and I am in no doubt that a generation of scholars who have benefited from that selfsame guiding hand will join us in celebrating his fruitful and generous contribution to the discipline.

Richard's significant impact stems not only from the professionalism with which he has edited the journal but from his fundamental good sense, kindness and humour. He has seen out the terms of a good number of my Cambridge University Press colleagues but I know that all have found in his company the same pleasure, and in his counsel the same trust, as I do 
today. On this, the occasion when he steps up the masthead to his new status as 'Founding Editor', we thank him deeply for his dedication, his insight and his friendship.

Daniel Pearce

Cambridge University Press

\section{Richard Wall: a co-editor's tribute}

Continuity and Change without Richard Wall at the helm - for months, I have realized that I needed to confront both the actual fact of the journal AW - After Wall - and, to complete the nautical metaphor, exactly what Richard's moving up the ladder to 'Founding Editor' will be 'like'. To what might one compare the loss? The simple fact is that it can't be done, at least in this dimension: it is almost beyond the imaginable.

This is simply because Richard and Continuity and Change are not discrete or separable entities. Recently, I saw Emanuel Ax play a Beethoven piano concerto. It was as if the piano was a part of his body, so comfortable was he with his instrument. So it is with Richard: his mastery of the editorial keyboard has been complete. No paper submitted to the journal went unread; no submitted paper did not attract copious marginalia in a hand that I believe only I am able to decipher; no paper of even the slightest intellectual merit did not receive a terse set of comments; no resubmit went unread; no non-native speaker of English's accepted paper went un-rephrased; no front or back cover, page proof, table of contents, abstract, editorial convention escaped his attention. Those who have had the privilege of joining him at the top of the masthead - Larry Poos, Phillipp Schofield and myself, and now Eilidh Garrett - have laboured extensively but (we would all confess, I believe) in Richard's giant, comforting shadow. Besides, we knew that if somehow we slipped, if our attention was momentarily captured by some academic or administrative chore, Richard would be there, and we knew that, due to his editorial virtuosity, an error that passed our eyes would not go unnoticed by his.

Lest we honour Richard only for his high threshold for withstanding editorial drudgery, let us remember what he has accomplished. His efforts 
brought to fruition a truly international journal of interdisciplinary historical sociology, as our joint mentor Peter Laslett was wont to call this awkward pastime. Demography, social history and the law were packaged together. It must also be recalled where this all began. We began our venture a long time ago. Maggie Thatcher and Ronnie Reagan were in their first terms, and crafting that 'special relationship'. About the only political figure still in power today who held the reins of government then is Colonel Gadaffi. The SSHA, our meeting point, was in its infancy and populated by academic 'outcasts' at worst, 'young turks' at best. The ESSHA was not even contemplated.

We dedicate this volume to Richard, and his 'special relationship' with Continuity and Change, not only because of the unending supply of ink in his red pen but because one cannot intelligently talk about kinship, then and now - let alone formulate a theory of kinship relations - without immersing oneself in his work. Indeed, though I have not made a count (I should, since after all counting is what we do), I reckon no author is cited more frequently in the endnotes to this issue, or in the previous 24 volumes, than is that modest, though cheerful, fellow known as 'R. Wall'.

It is for these accomplishments that we dedicate this volume to him, to one more set of articles now safely in print, and with it we remind him that even upstairs, in the lofty domain of the Founding Editors, there is still much work for him, and only for him, to do. 